\title{
Higher Education in the United States
}


Aligning American Higher Eduation with National Priorities

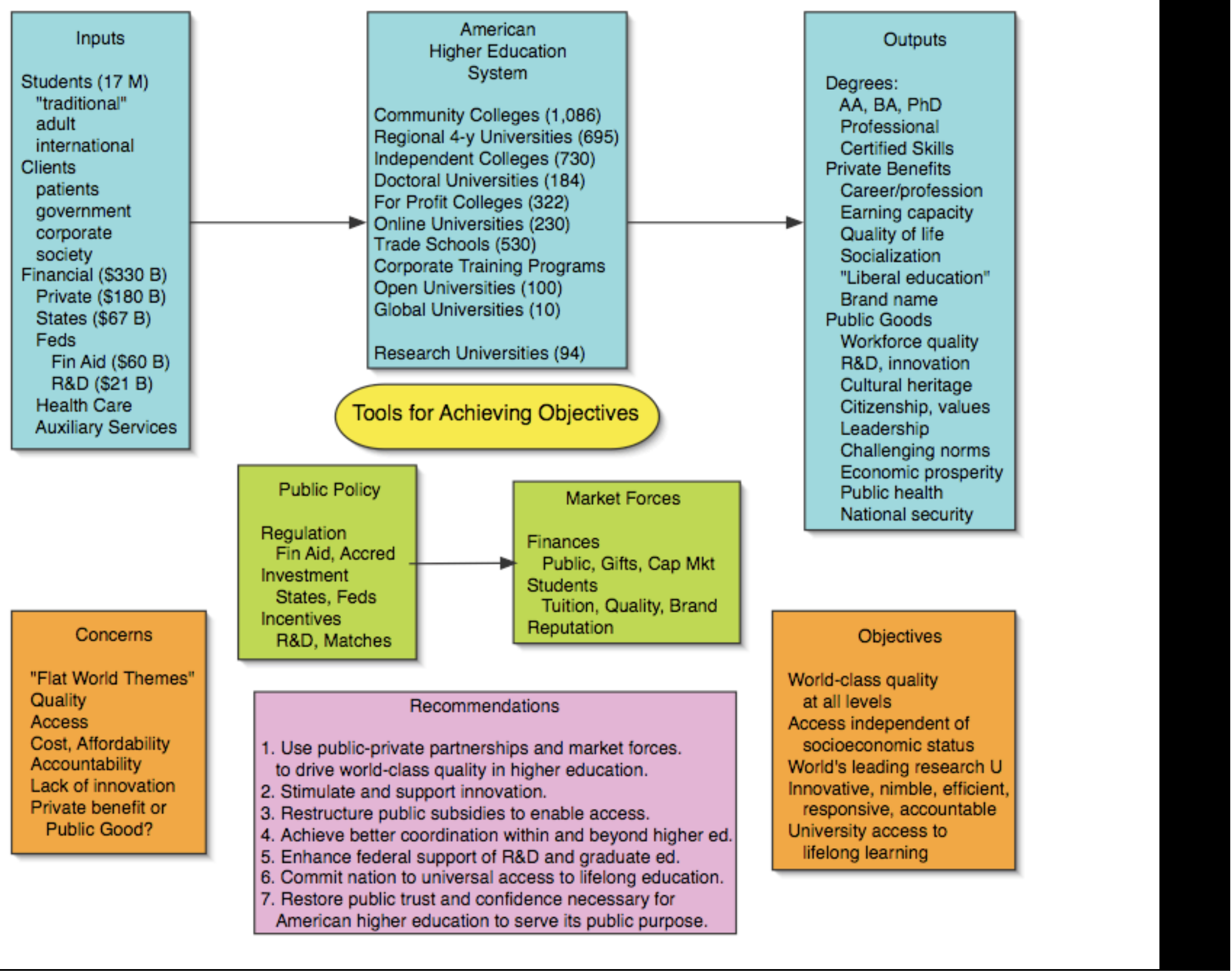




\section{Traditional Roles of the University: The Core}

Educating the Young

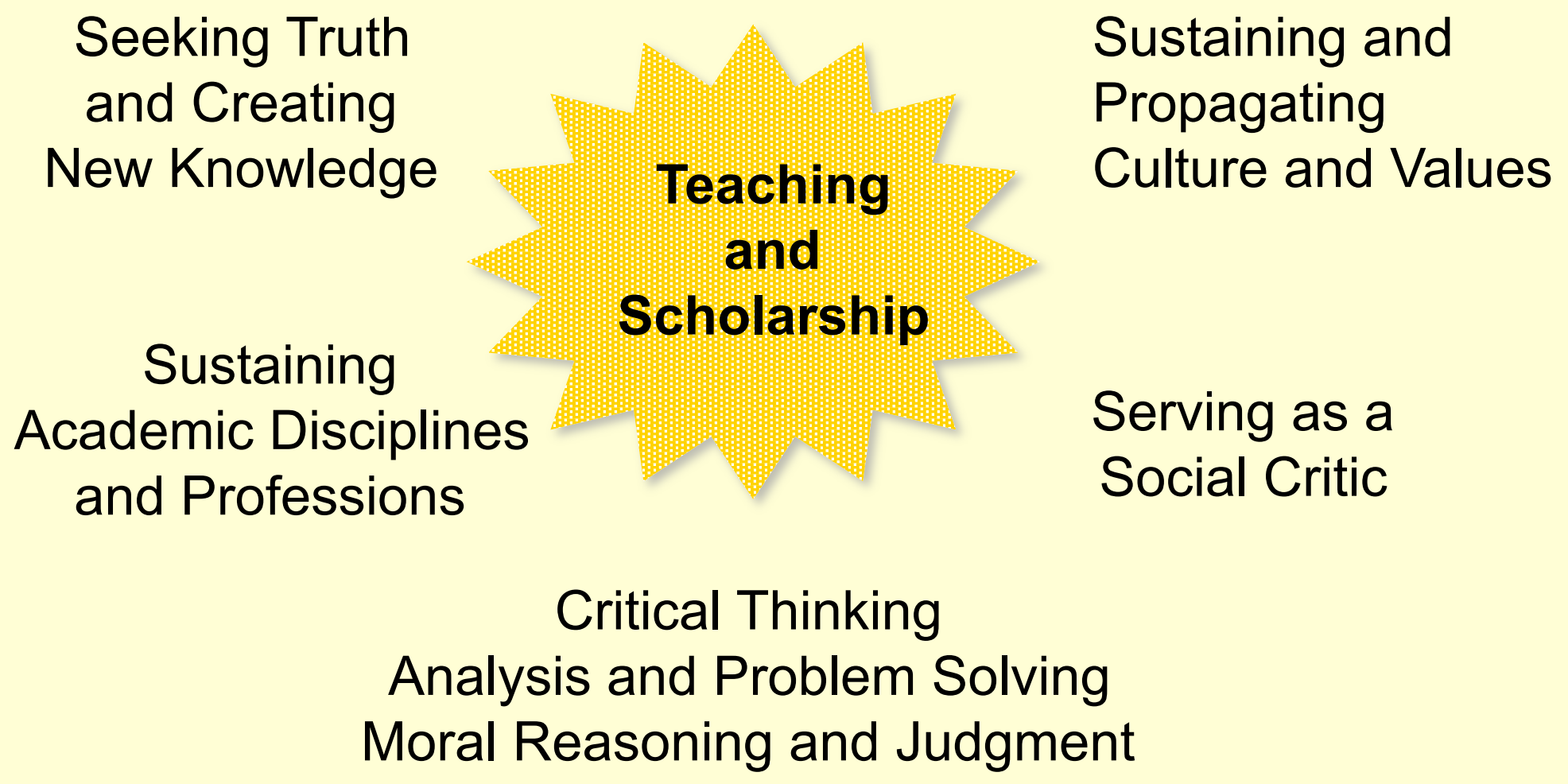




\section{The Periphery}

Economic Development

(Agriculture, Industry, etc.)

Technology Transfer

Entertainment (Arts, Sports)

Health Care

Teaching and Scholarship

National

Defense

International Development 


\section{The Evolution of U.S. Higher Education}

1700s-1800s

Colonial colleges (elite, private)

1860s

Land-grant state universities

$1900 \mathrm{~s}$

Normal colleges, technical colleges

$1950 \mathrm{~s}$

Research universities, community colleges

$1960 \mathrm{~s}$

State university systems

2000 and beyond

For-profit U, cyber U, global U, ... 


\section{U.S. Colleges and Universities}

Public 4-year institutions

Private 4-year institutions

Public 2-year institutions

Private 2-year institutions

For-profit institutions

Total
634

1,546

1,086

118

852

4,236 


\section{Types of Colleges \& Universities}

Major research universities

94

Other doctoral universities

184

Regional universities

695

Baccalaureate colleges

730

Community colleges

1,086

Other (religious, specialized, etc.) 1,446 


\section{Enrollments}

Total enrollments (2003)

17.3 million

Percentage of population with some college

$53.9 \%$

Percentage of population

with BA/BS degree

$26.6 \%$ 


\section{Finances}

State support (20\%)

Federal support (25\%)

Student financial aid

Research grants

Private support

(tuition, gifts) (55\%)

Total support

(2.6\% GDP)
$\$ 67$ billion

$\$ 60$ billion

$\$ 21$ billion

\$180 billion

$\$ 330$ billion 


\section{Role of Government}

Federal Government

No ministry, no national systems, no controls... no policy $\$ 60$ billion/y of financial aid to students

$\$ 21$ billion/y of research grants to individual faculty

NOTE: The federal government provides grants to people (students, faculty, patients), NOT to universities

State Government

$\$ 60$ billion/y to support operation of public universities Great diversity in state governance, from rigidly controlled systems (New York, Ohio) to strategic master plans (California) to anarchy (Michigan) 


\section{Other Characteristics}

- The great diversity among institutions and missions.

- The balance among funding sources (private vs. public, state vs. federal).

- The influence of market forces (for students, faculty, resources, reputation).

- Its global character (attracting students and faculty from around the world)

- The absence of a centralized system that leads to highly decentralized, market-sensitive, and agile institutions, students, and faculty.

- Supportive public policies (academic freedom, institutional autonomy, tax and research policies).

- The research partnership between universities, the federal government, and industry. 


\section{Other Characteristics}

- The great diversity among institutions and missions.

- The balance among funding sources (private vs. public, state vs. federal).

- The influence of market forces (for students, faculty, resources, reputation).

- Its global character (attracting students and faculty from around the world)

- The absence of a centralized system that leads to highly decentralized, market-sensitive, and agile institutions, students, and faculty.

- Supportive public policies (academic freedom, institutional autonomy, tax and research policies).

- The research partnership between universities, the federal government, and industry. 
Aligning American Higher Eduation with National Priorities

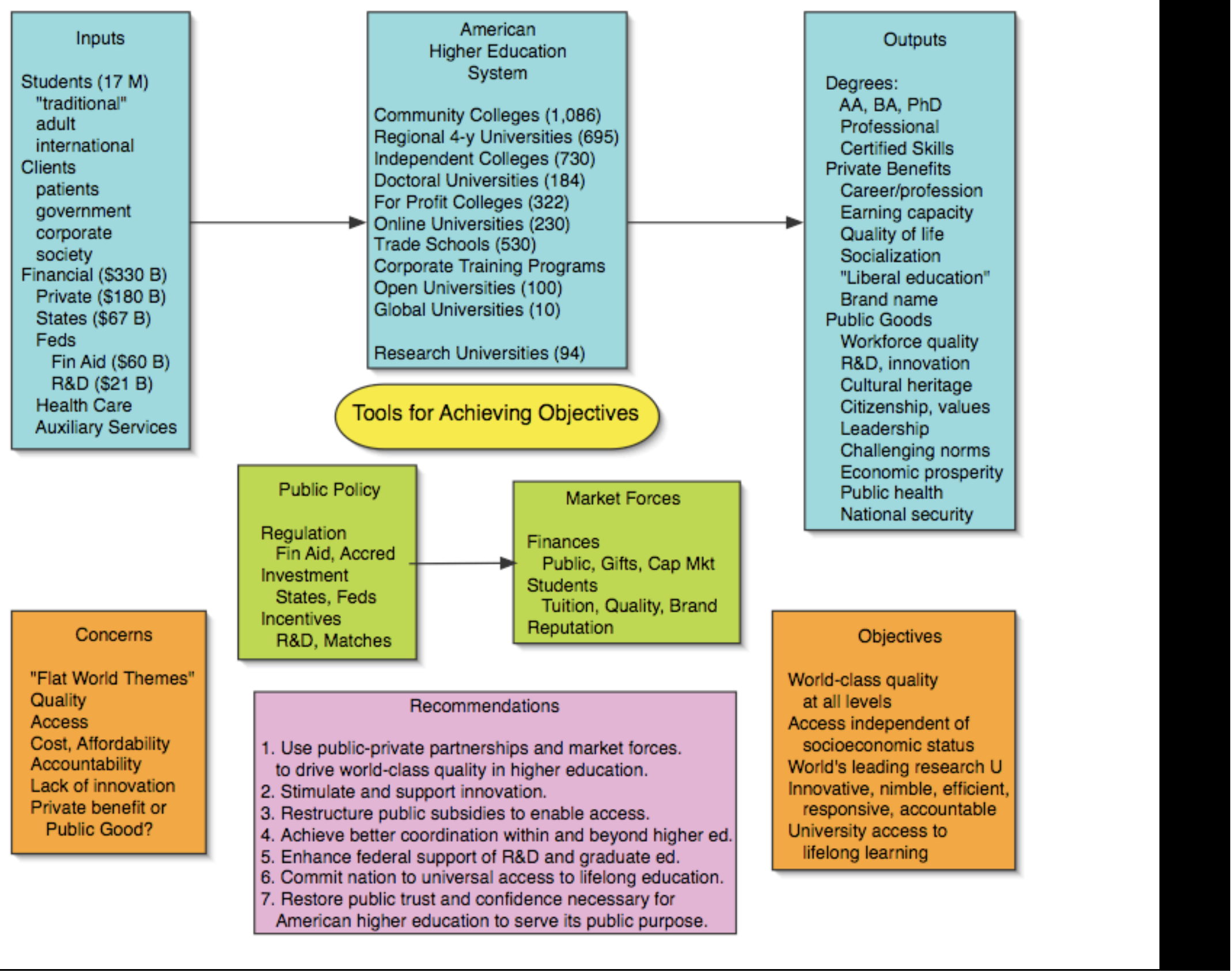




\section{The Evolving U.S. Education System}

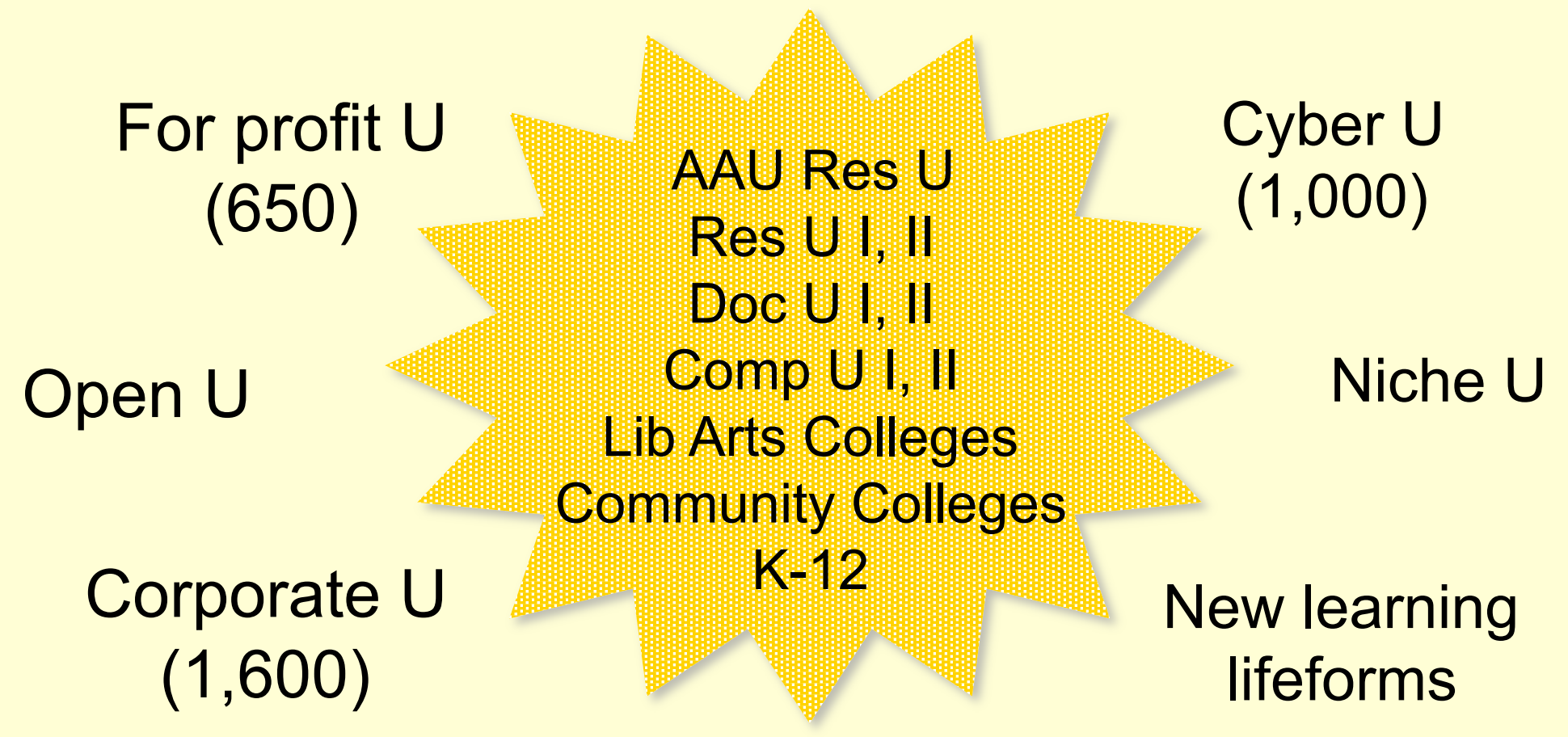

Knowledge Infrastructure (production, distribution, marketing, testing, credentialling) 


\section{The Evolving U.S. Education System}

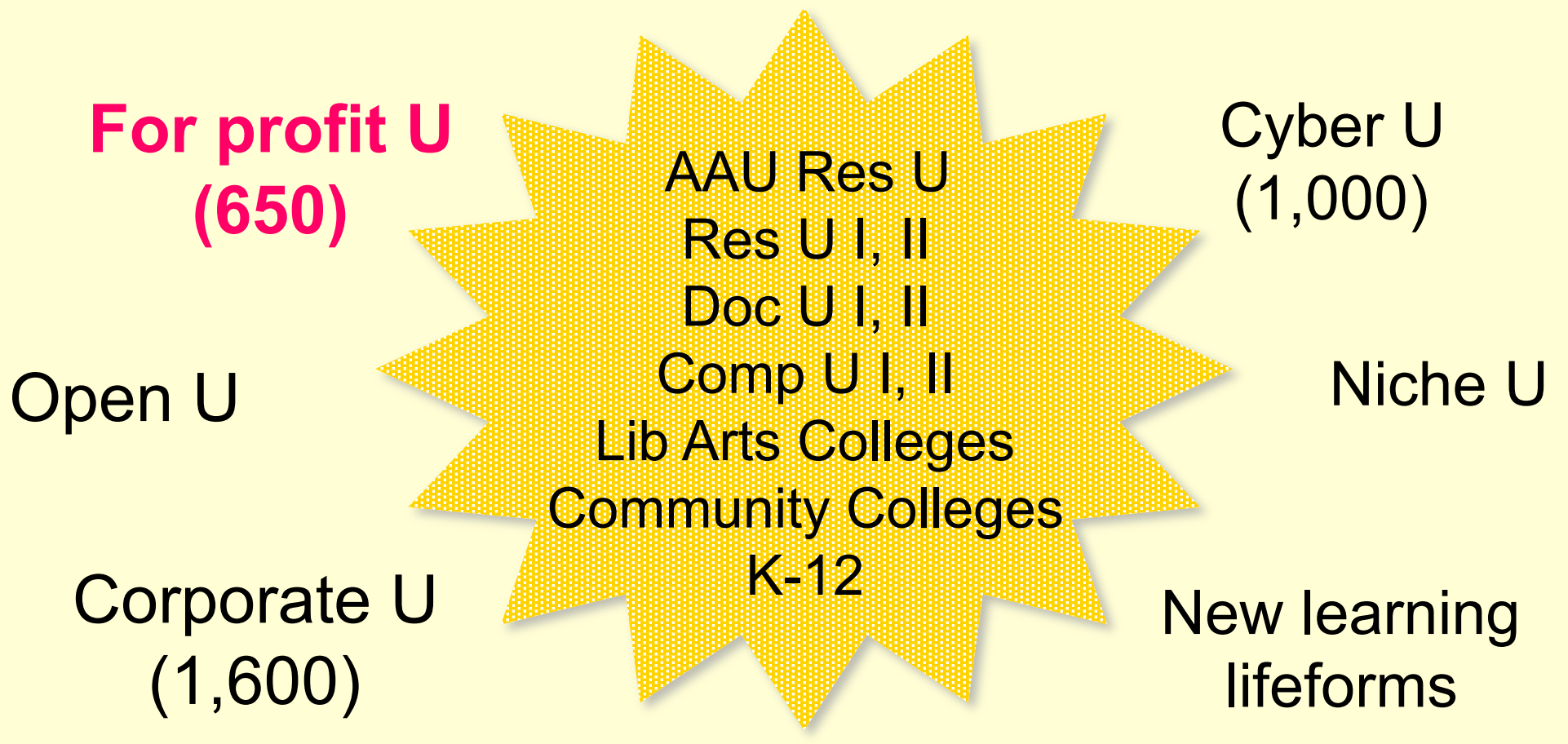

Knowledge Infrastructure (production, distribution, marketing, testing, credentialling) 


\section{Suniversityof}

University of Phoenix:

chosen by more working professionals than any other university in the U.S.

\section{Accreditation}

\section{Financial Aid}

$\underline{\text { FlexNet(8) Internet Courses }}$
Attend classes at a convenient

$>$ campus location, in the evening or on weekends.

$>$ Earn your degree in 2 - 3 years, in most cases.

Acquire the most important industry skills.

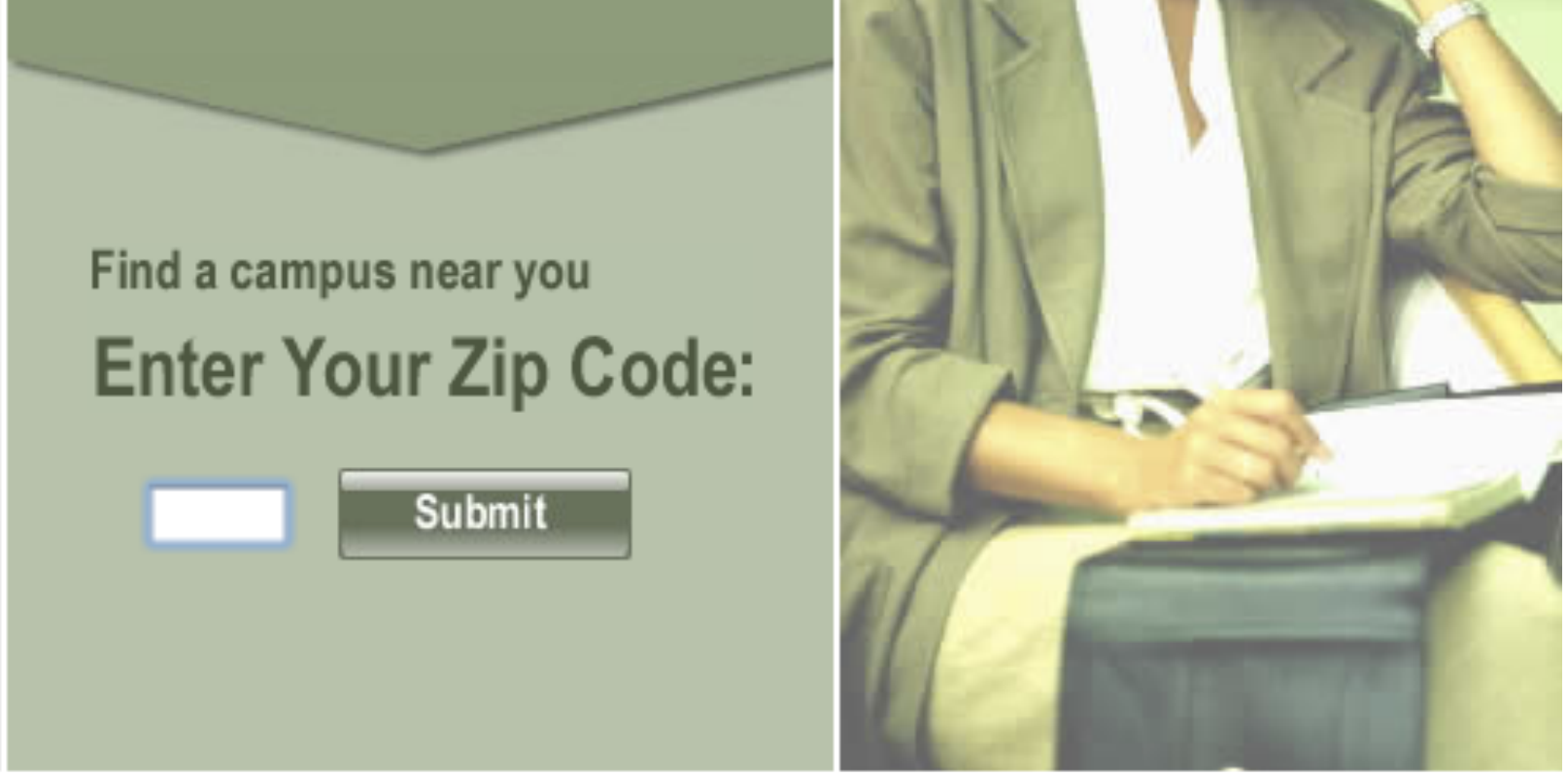

Home I Accreditation I Privacy Policy 


\section{The Evolving U.S. Education System}

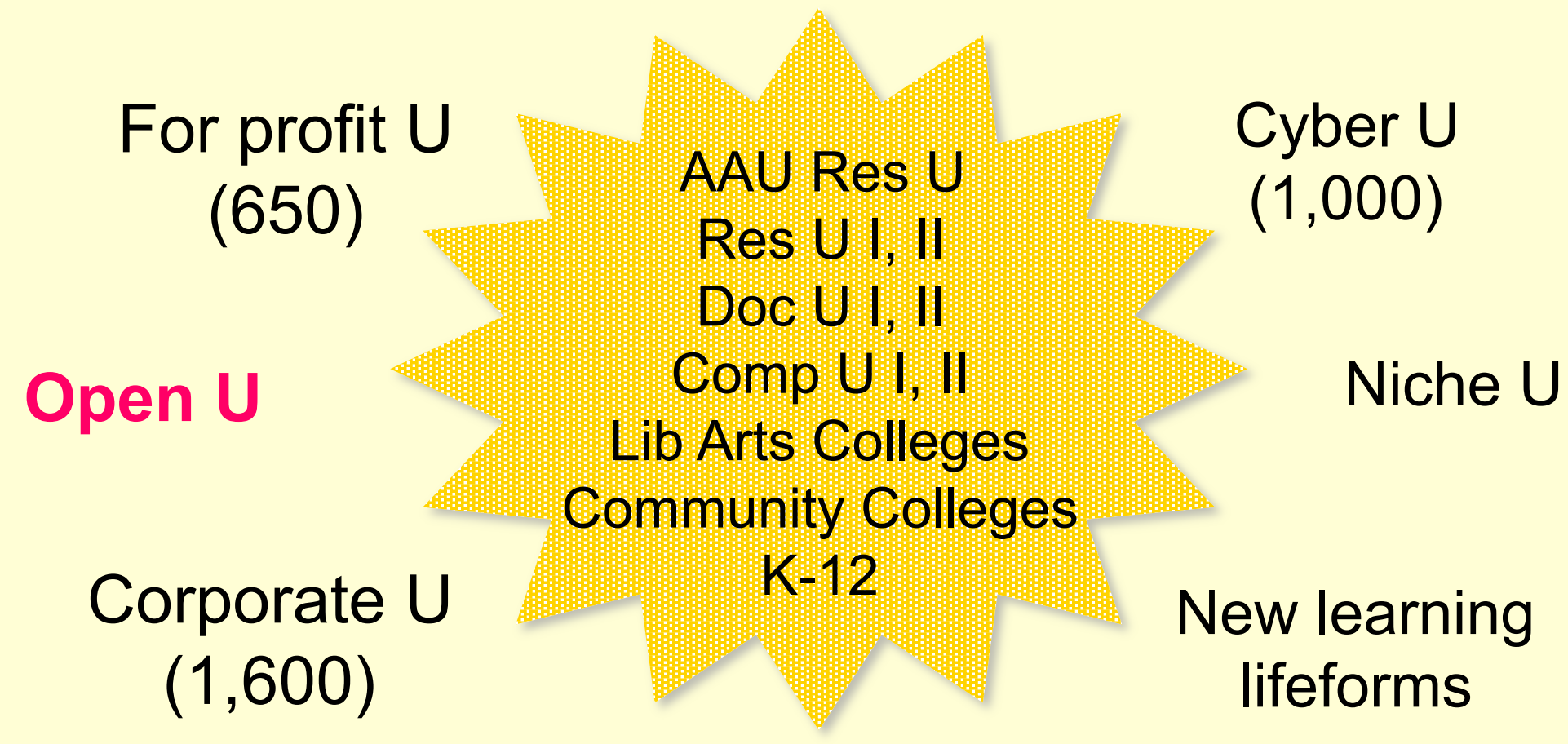

Knowledge Infrastructure (production, distribution, marketing, testing, credentialling) 
text only

Open University

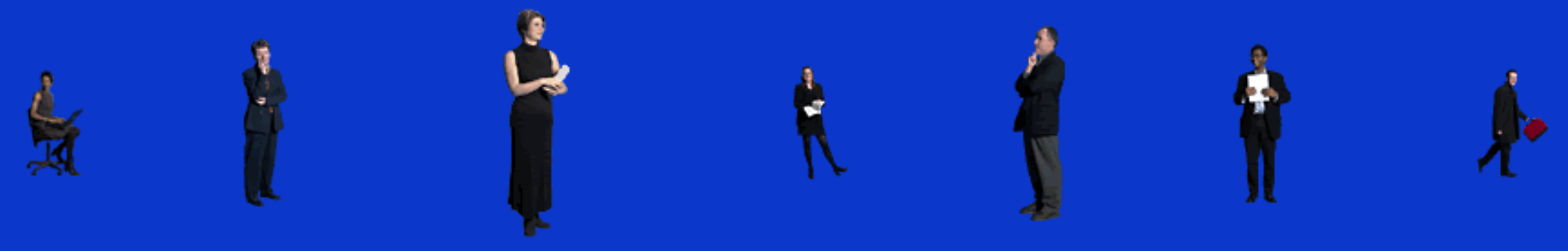

open as to method

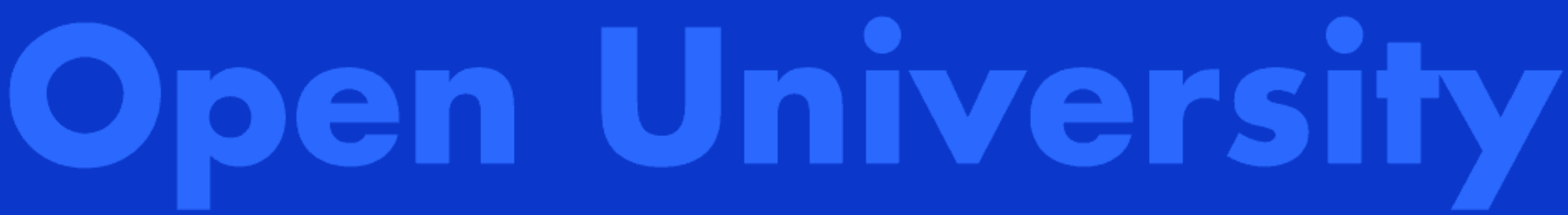

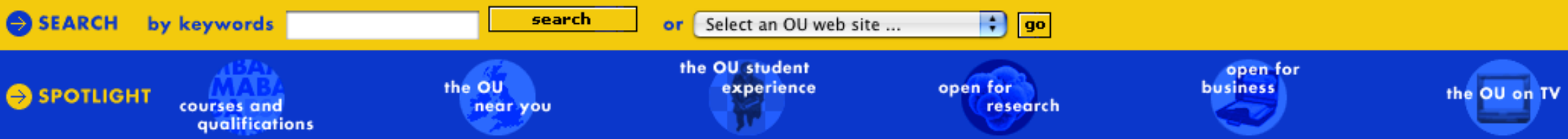




\section{The Evolving U.S. Education System}

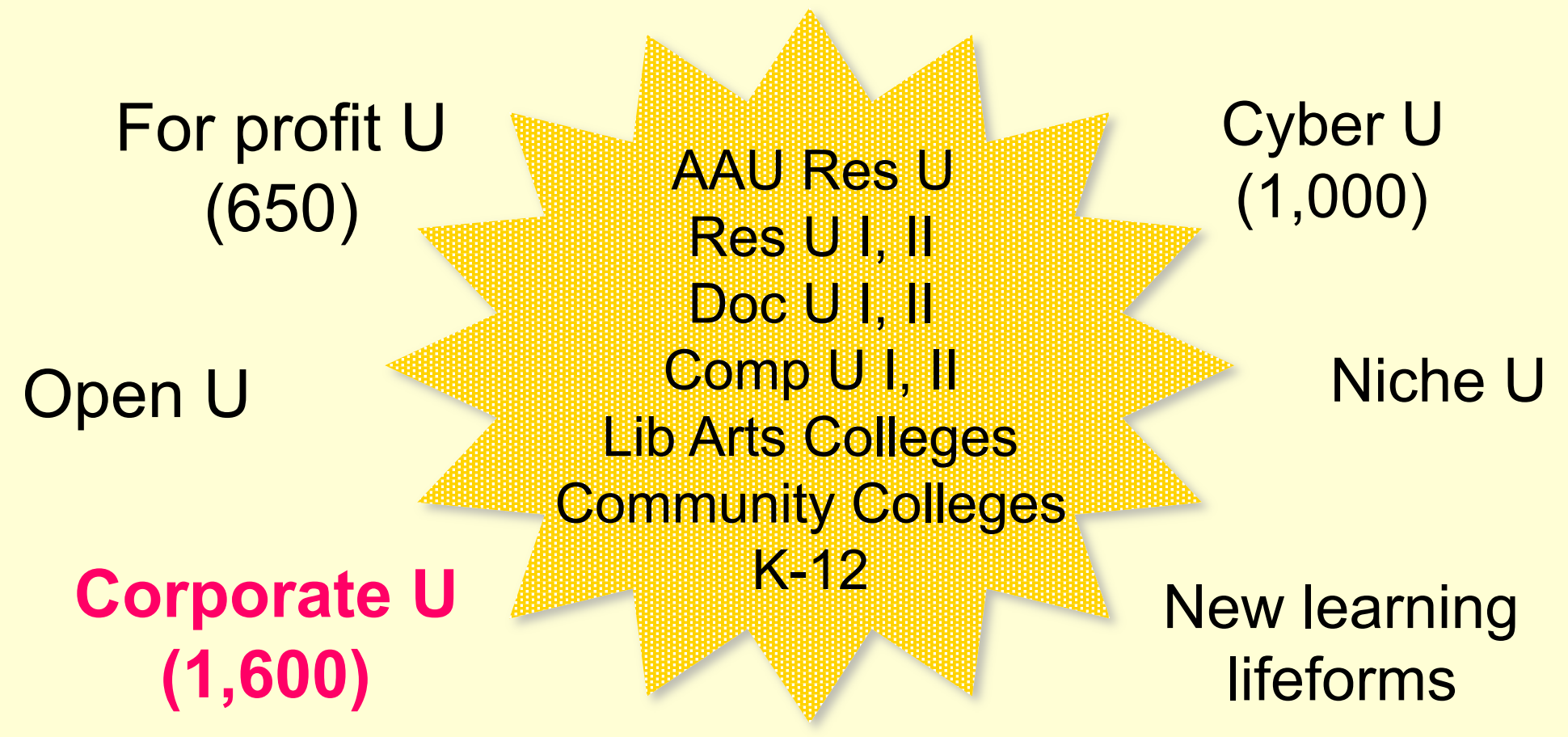

Knowledge Infrastructure (production, distribution, marketing, testing, credentialling) 


\section{McDonald's Corporation}

\section{I'm lovin' it}

\section{ABOUT MCDONALD'S \\ INVESTORS \\ FRANCHISING \\ NEWS \\ CAREERS}

OUR VALUES

\begin{tabular}{|l}
\hline Business Functions \\
Employee Benefits \\
Recognition \\
Contact Information \\
Hamburger University \\
Search Jobs \\
\hline
\end{tabular}

\section{Hamburger University}

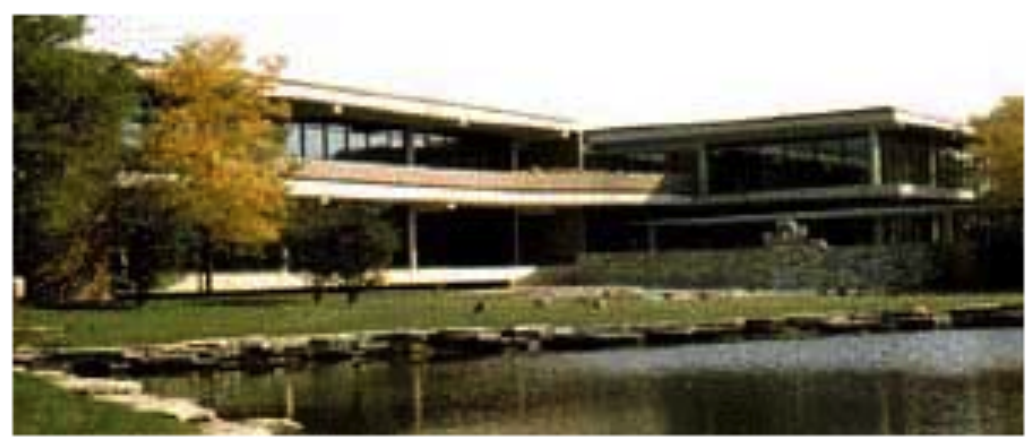

Hamburger University is McDonald's worldwide management training center

Hamburger University is McDonald's worldwide management training center located in Oak Brook, Illinois. Designed exclusively to instruct personnel employed by McDonald's Corporation or employed by McDonald's Independent Franchisees in the various aspects of the business. All training programs begin with one essential ingredient: The Basics of McDonald's Operations.

Founded in 1961, Hamburger University's has come a long way since we opened our first training facility in the basement of a McDonald's restaurant in Elk Grove Village, Illinois. Since that time we've moved Hamburger University twice and watched the size of classes grow from an average size of about 10 to more than 200

\section{STOCK}

Current Price: $\$ 28.90$

Change: \$-.11

as of 4-07-04 15:10 CT

Stock split and dividend

\section{NEWS}

\section{Corporate}

03/08/2004 McDonald's

Revitalization Plan Delivering

Results

03/05/2004 McDonald's Sales

Momentum Continues; Reports

Record February Sales, Up 23\%

02/17/2004 McDonald's Reports Record \$3.3 Billion Cash Flow for 2003; Releases 2003 Cash Flow

Statement

USA

12/30/2003 McDonald's Applauds and Supports

Leadership Actions Taken by USDA 


\section{UNiSYS}

Imagine it. Done.

\section{Careers Home}

Company Profile > Careers > Growth and Development >

$<$ Back to Growth and Development

\section{Growth and Development \\ Unisys University}

\section{Our Global Corporate University}

Created to meet the learning needs of Unisys employees, the university offers classroom and online training on a large variety of subjects related to our business. Employees enroll in courses to gain new skills, certifications and knowledge to advance their careers and the success of our business.

The University is open to all employees and there is no limit on the number of courses a student can take. Five campuses, located throughout the world, provide training to employees in every geographic region.

Our eight schools address the most pressing needs of our business and constantly update their courseware to meet the current and future needs of our business. 


\section{The Evolving U.S. Education System}

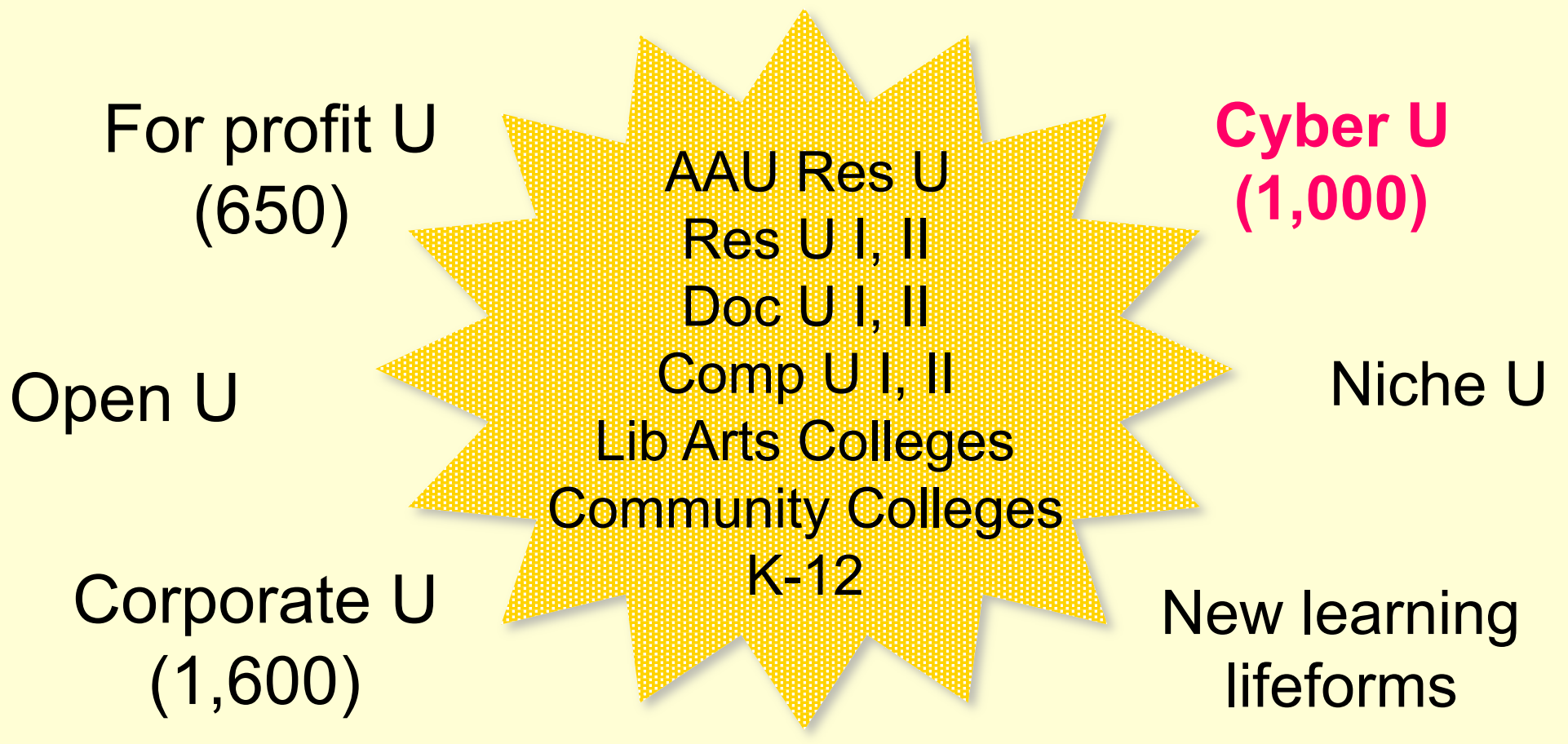

Knowledge Infrastructure (production, distribution, marketing, testing, credentialling) 

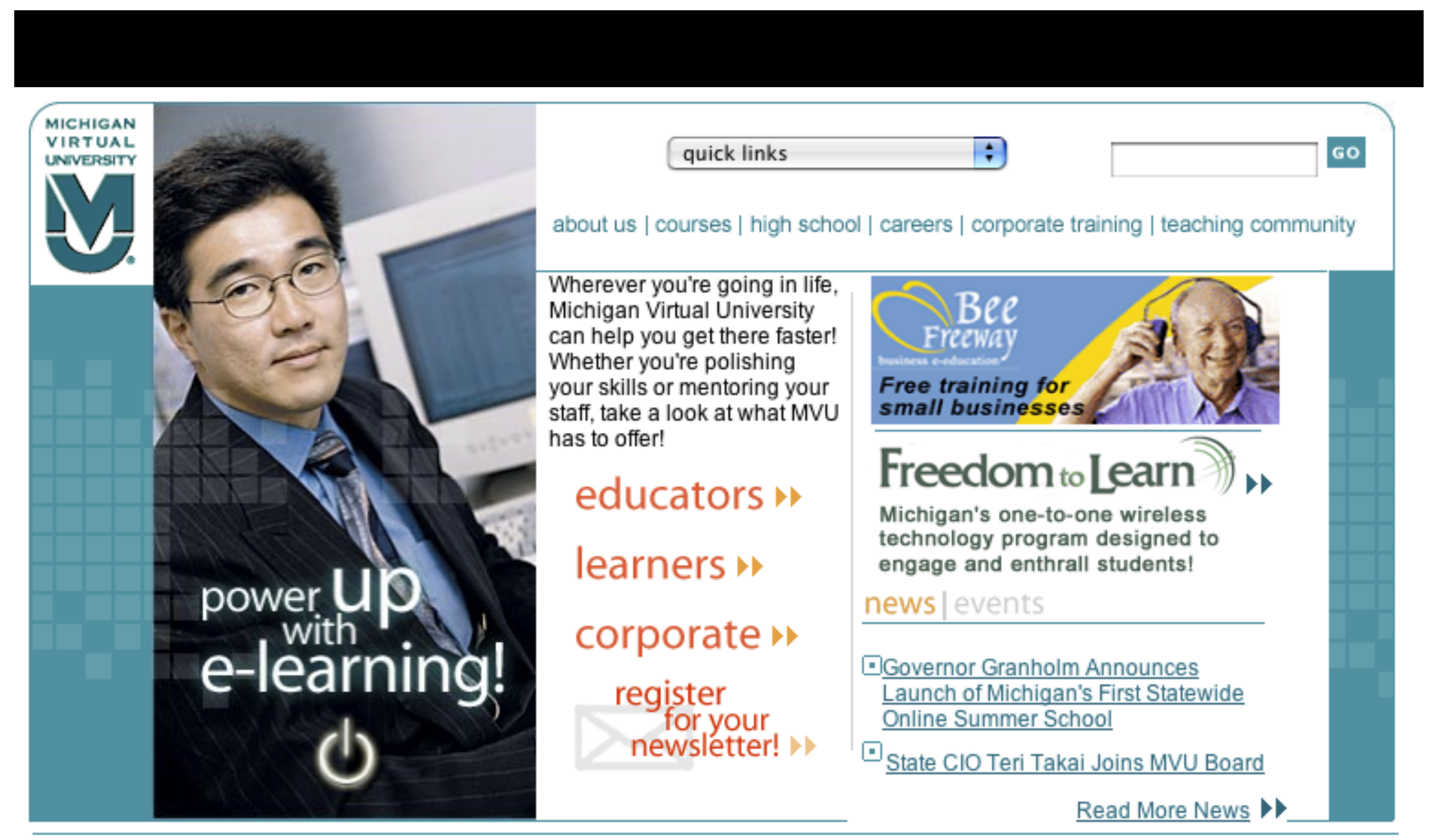

help contactus privacy policy site map 2004 Michigan Virtual University 


\section{The Evolving U.S. Education System}

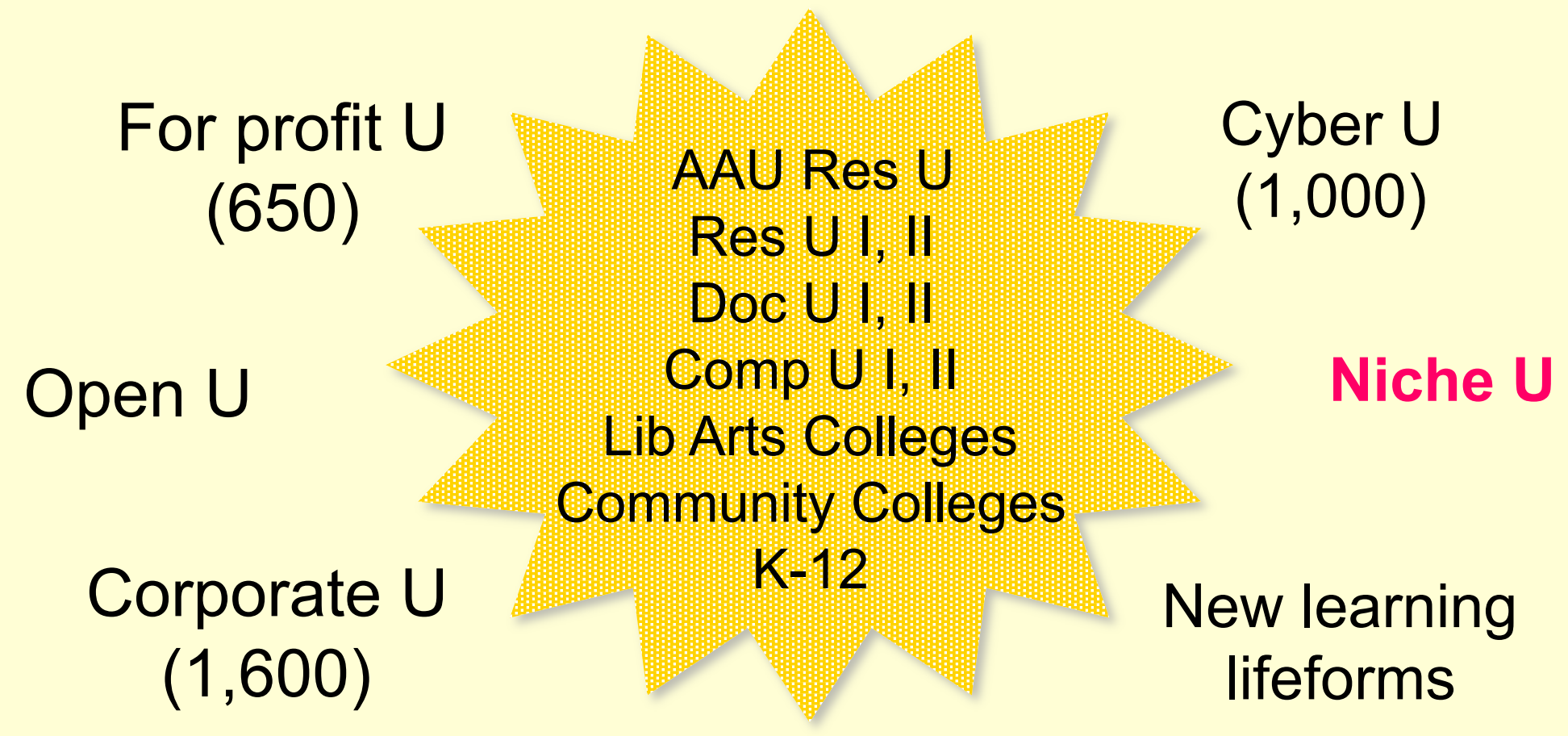

Knowledge Infrastructure (production, distribution, marketing, testing, credentialling) 


\section{The Evolving U.S. Education System}

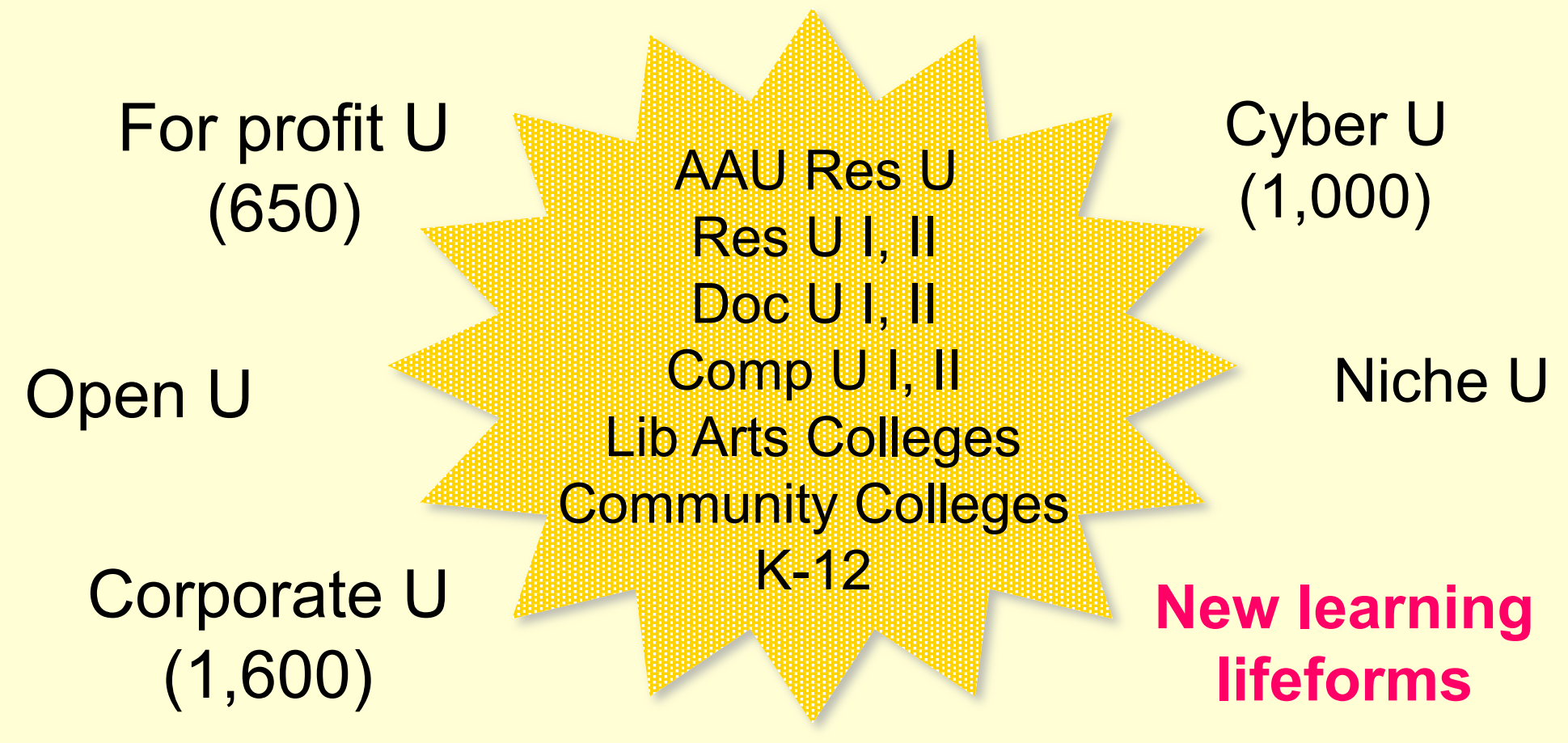

Knowledge Infrastructure (production, distribution, marketing, testing, credentialling) 


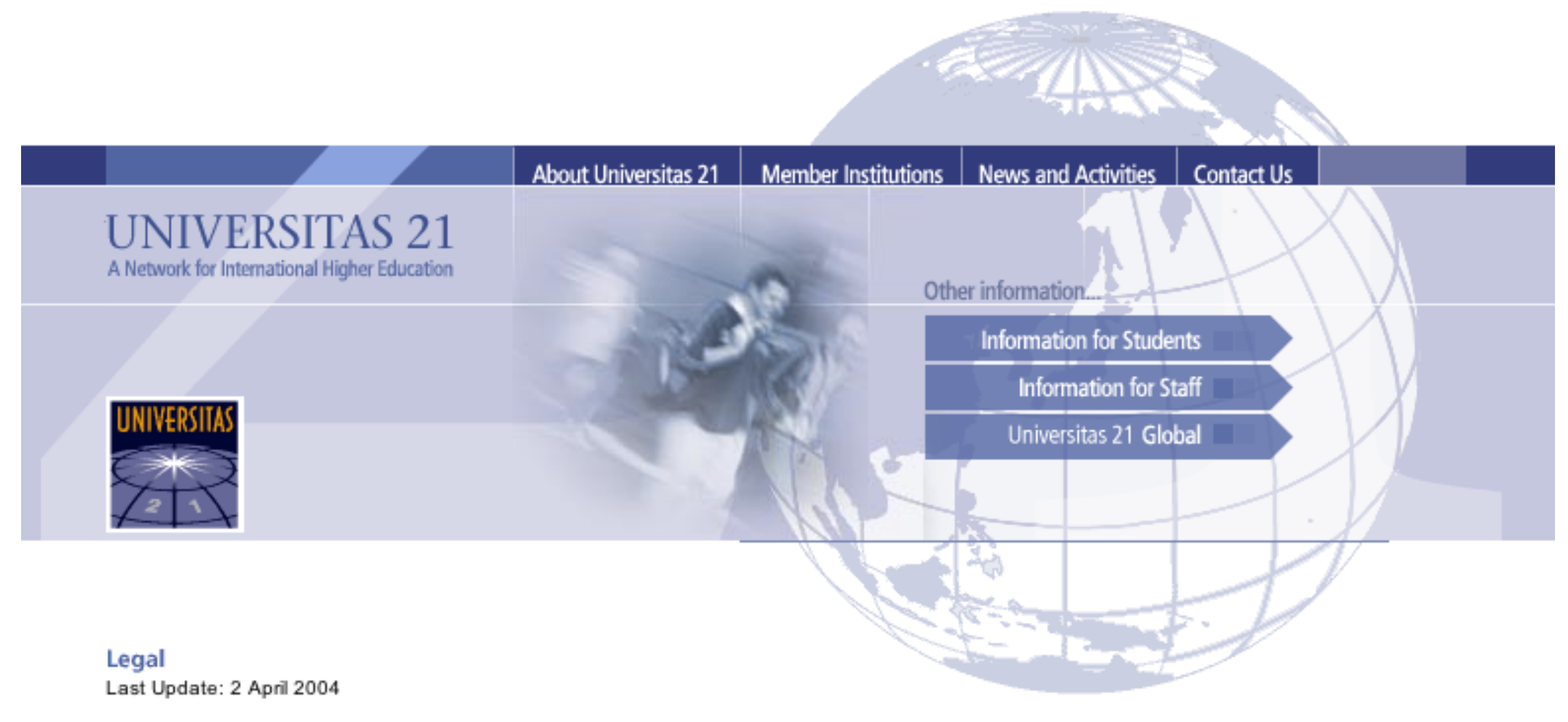




\section{A TEST OF LEADERSHIP}

Charting the Future of U.S. Higher Education

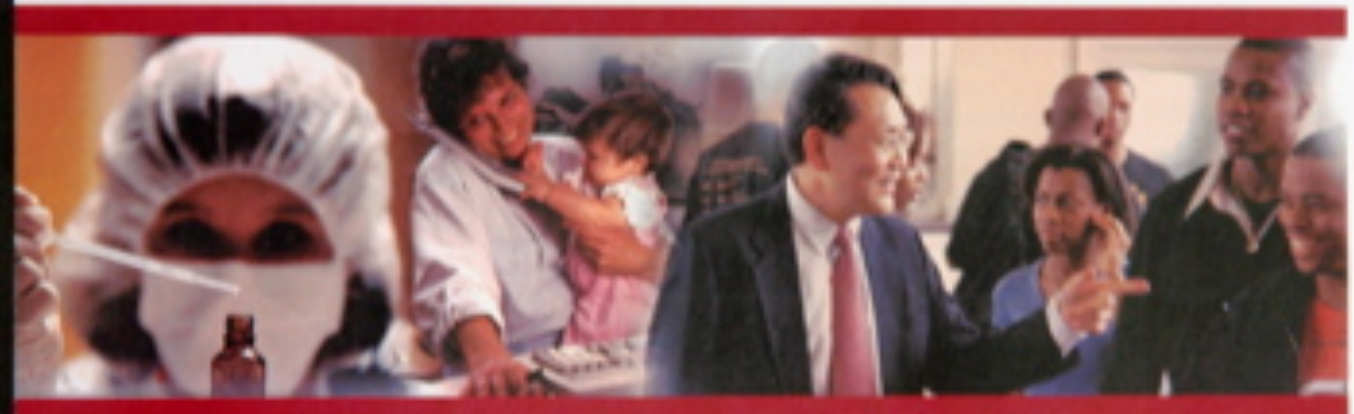

Pro-Publication Copy Soptember 2006 


\section{RISING ABOVE}

THE GATHERING Energizing and STORM

Employing America

for a Brighter

Economic Future

\section{$4 \%$}




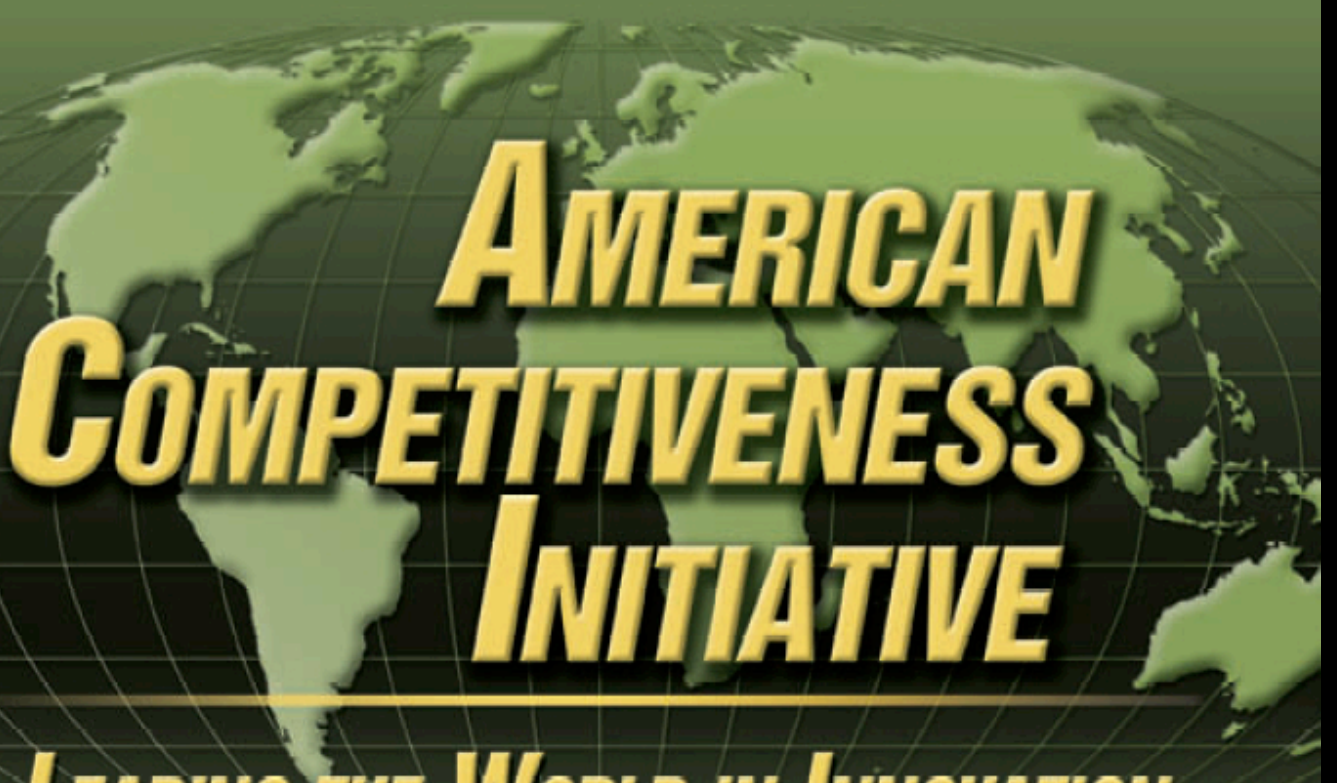

LEADWG THE WOBLD IN WWOVATION

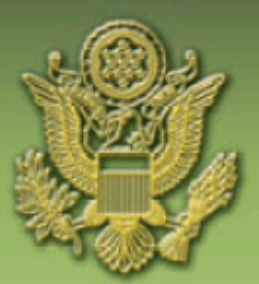

IVIIESIIt

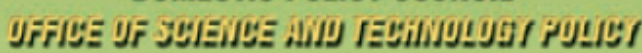

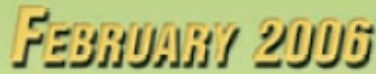




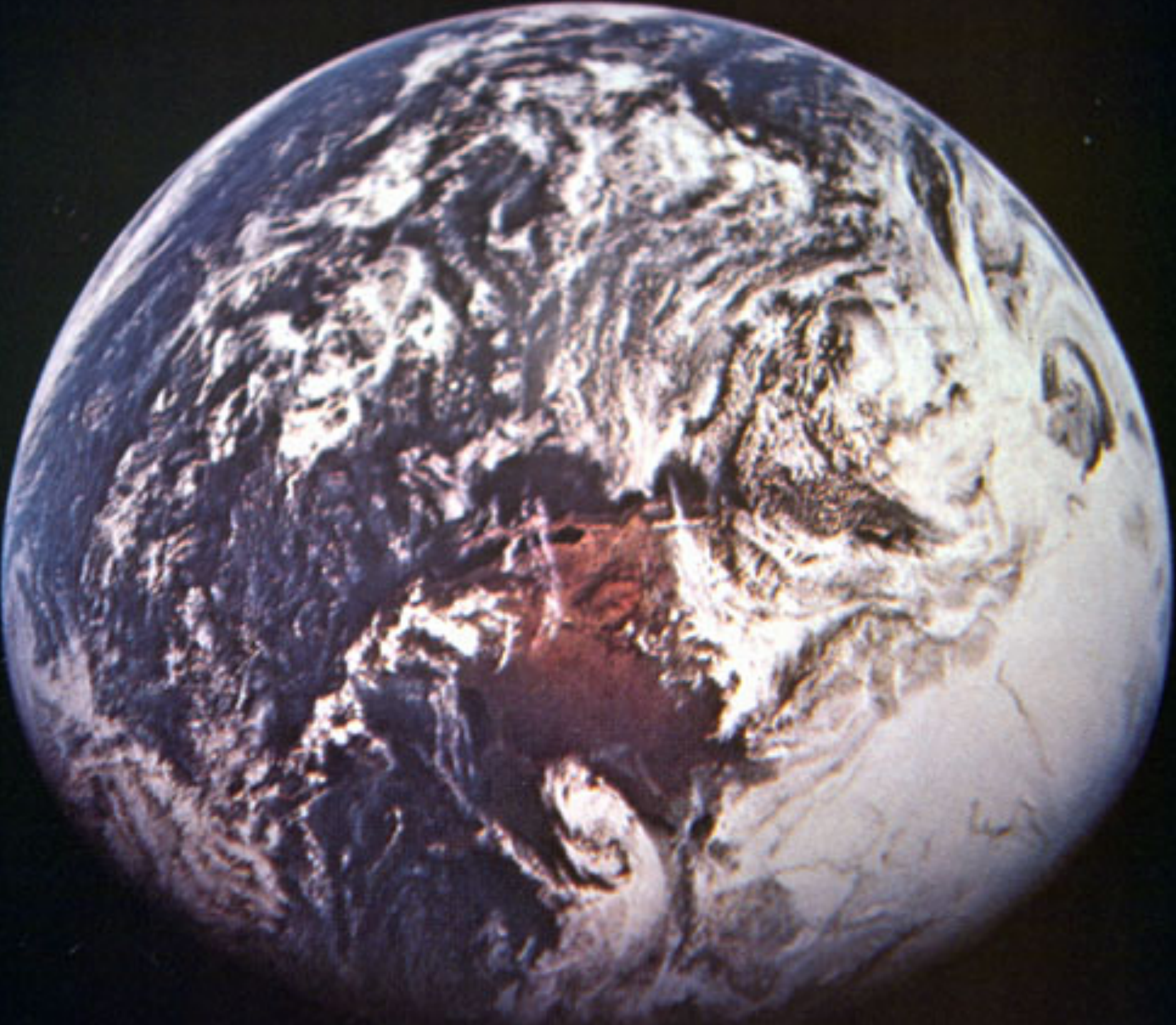




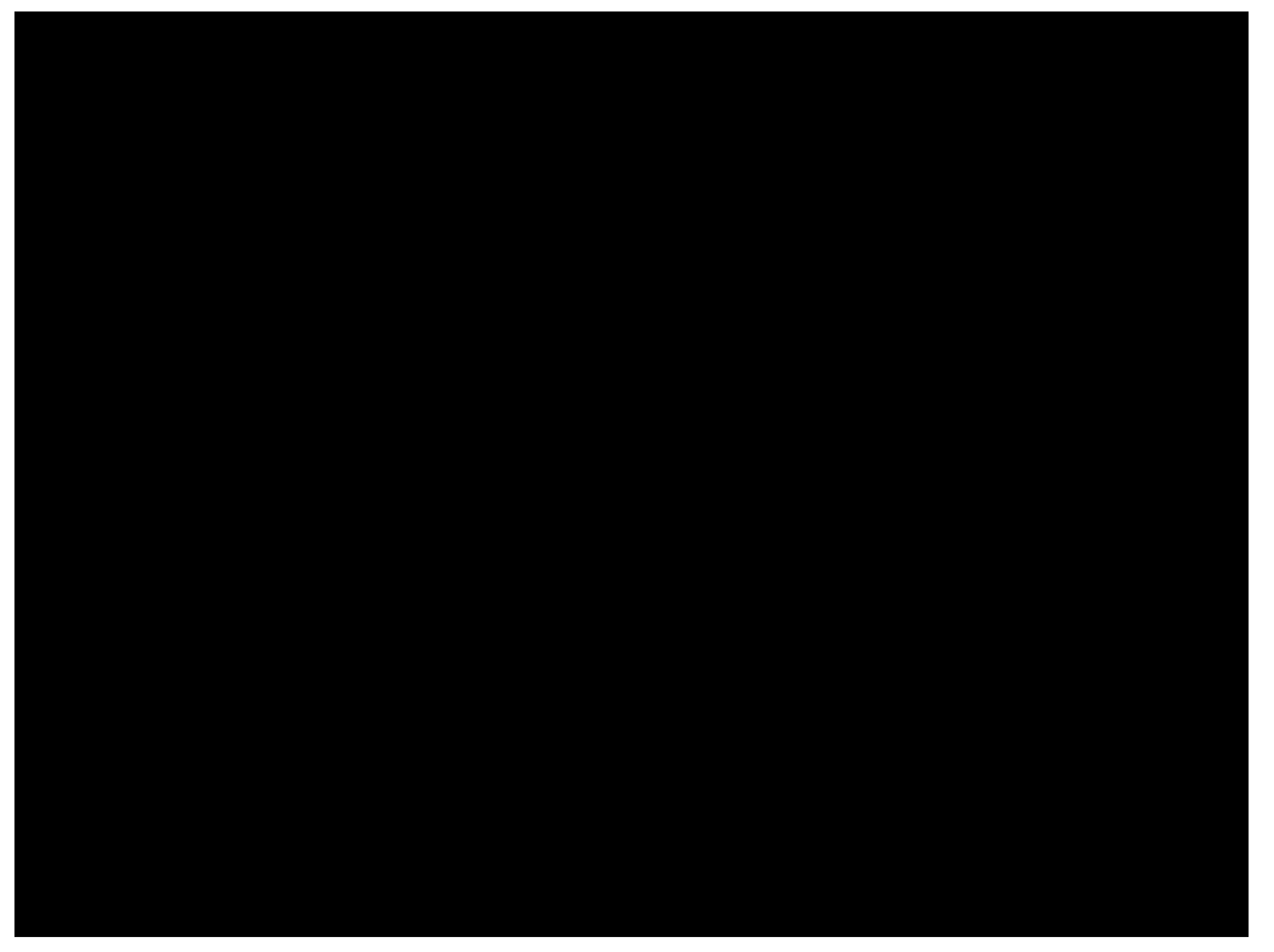

